\title{
Are Real Options a missing piece in the Diversification-Value Puzzle?
}

\author{
Pablo de Andrés ${ }^{\mathrm{a}}$, Gabriel de la Fuente ${ }^{\mathrm{b}}$, Pilar Velasco ${ }^{\mathrm{c} *}$
}

a Autonoma University of Madrid, Department of Finance, Cantoblanco Campus-28049 Madrid (Spain). Phone: +34 91497 6527. E-mail: p.andres@uam.es

b University of Valladolid, Department of Financial Economics and Accounting, Avenida Valle del Esgueva, 6-47011 Valladolid (Spain). Phone: +34 983 423334. E-mail: gabriel.fuente@uva.es

c* Corresponding author. University of Alcalá, Department of Economics and Business, Plaza Victoria s/n-28802 Alcalá de Henares, Madrid (Spain). Phone: +34 918855217. E-mail: mpilar.velasco@uah.es

\section{Acknowledgements:}

Financial support has been received from the Regional Government of Castilla y León (Ref. VA260U14), the Spanish Ministry of Science and Innovation (Ref. ECO2014-56102-P), the Spanish Ministry of Education (FPU Programme), and the Banco Herrero Foundation. Pilar Velasco wishes to thank the London Business School (LBS) for their hospitality during her research stay there. 


\title{
Are Real Options a missing piece in the Diversification-Value Puzzle?
}

(This version: $18^{\text {th }}$ April, 2016)

\begin{abstract}
This paper examines the impact of corporate diversification on a firm's market value in terms of changes in its mix of value sources between growth options and assets-in-place. We argue that the traditionally assumed replicability of corporate diversification benefits by individual investors might not be as feasible when diversification implies acquiring new growth options as when it only involves assets-in-place investments. We further explain why a different effect of diversification on a firm's mix of value sources can occur, therefore leading to a mediating role of growth options between diversification and market value. Using a panel sample of U.S. firms from 1998 to 2010, we find that a firm’s growth options portfolio helps explain the effect of diversification strategy on its market value.
\end{abstract}

Keywords: corporate diversification, firm value, growth opportunities, GMM, mediating effect.

JEL Classification: L25, G32, D22, C34. 


\section{Introduction}

This paper focuses on analysing the possible mediating role played by a firm's growth opportunities on the value of corporate diversification. Most prior literature has been concerned about the analysis of the impact of this corporate strategy on the firm's market value as a whole, without discerning the nature of such value effect. However, a firm's market value is primarily composed of two elements: the assets-in-place value and the growth options value (Myers, 1977). Separating these two components is worthwhile when analyzing value effects since while a firm's diversification in assets-in-place might be reproduced by stockholders within their own investment portfolios in perfect capital markets, as stated by Amihud and Lev (1981), growth options diversification is not so easily replicable. Should growth options be a component of a firm's value and should corporate diversification impact on a firm's growth options, analysis of the diversification-value linkage will not be complete without considering the relation between these three variables: diversification, growth options and value.

A few papers, such as Berger and Ofek (1995) and Mansi and Reeb (2002), have added growth opportunities as a control variable when testing for the effect of diversification on value. Ferris et al. (2002) analyze diversification for a sample of international joint ventures and show that diversification is only value-destroying in enterprises that have a poor set of growth opportunities. More specifically, Stowe and Xing (2006) analyze whether the diversification discount is attributable to differing growth opportunities between each business segment within a diversified firm and its single-segment industry counterpart. They find that a firm's excess value becomes significantly lower after firms diversify and that this diversification discount is not driven by a firm’s future growth opportunities. Yet, their results depend critically on how growth opportunities are measured. Following Lang et al. (1996), 
Stowe and Xing select the ratio of capital expenditures to total assets as a measure of growth opportunities. Such a ratio may not be the best forward looking proxy for growth opportunities in all cases, the main reason being that it captures their exercise (of these growth options) to a greater extent than their possession ${ }^{1}$.

Selecting an accurate variable to proxy an unobservable variable such as a firm's growth opportunities clearly poses a major challenge. Market-to-book ratios and Tobin’s Qs are widely used in the literature as proxies for growth opportunities but are influenced by the same market values on which usual measures of diversification excess value (such as Berger and Ofek's) are based. Instead, two alternative variables can easily be used to alleviate these concerns: return skewness (Andrés et al., 2006; Haanappel and Smit, 2007) and growth opportunities residuals (Brown and Perry, 1994; Servaes and Tamayo, 2013). Such estimates are related to growth opportunities while remaining free of the influence of excess value.

Apart from analysing the empirical evidence through the lens of these alternative proxies, our study also contributes to the diversification literature by offering further insights into the trinomium involving diversification, growth opportunities and firm value. According to the real options (RO) approach, corporate diversification involves replacing the option to diversify, which is exercised, with both assets-in-place and further growth options. As a consequence, the net effect of a diversification decision on the relevance of growth opportunities within a firm's total assets portfolio (growth opportunities relevance, hereinafter GOR) will depend on the sign of the acquired assets-in-place's Net Present Value (hereinafter NPV). Should this be positive, diversification would imply lower GOR, as a result of

\footnotetext{
${ }^{1}$ Stowe and Xing (2006) assume that the higher the capital expenditures to total assets, the more relevant the growth opportunities are. However, a firm which has exhausted its growth opportunities will report a high value in the ratio of capital expenditures to total assets, whereas a firm with a large amount of growth options optimally unexercised will be assigned a low value. This problem has been noted in earlier works such as Dhaliwal et al. (1999).
} 
replacing the higher value of the exercised growth option by the lower value of new growth options. The opposite effect would appear in the case of a negative assets-in-place NPV, such that greater diversification would imply higher GOR.

We further argue that the degree of diversification may exhibit a U-form relationship with GOR. The logic underlying this relation is based on managers' widespread preference for positive NPV projects as shown by the more frequent use of NPV models vis-à-vis real options models (Graham and Harvey, 2001). Such a preference suggests that managers would be more likely to first exploit their most profitable options in terms of their assets-in-place's NPV. As a result, within these low diversifiers, greater diversification would display a lower GOR. At the opposite extreme, highly diversified firms would be those investing simultaneously in multiple options, many with negative assets-in-place NPV. In these latter cases, greater diversification would show higher GOR. Moreover, insofar as growth options and their optimal joint exercise policy are unique and cannot be replicated by investors in their individual portfolios, this relationship between diversification and growth options may be transmitted to the firm value. As a consequence, a mediating role of growth opportunities in the diversification-value relationship should be expected.

Using a final panel sample of 4,053 U.S. firm-year observations from 1998 to 2010, our findings support the quadratic relationship between the degree of diversification and GOR. At low levels of diversification, the higher the degree of diversification, the less relevant growth opportunities prove to be. However, we find a diversification level after which this strategy materializes into new growth options to a greater extent and therefore into an increase in GOR. Secondly, we report evidence about the partial mediating role of GOR in the diversification-value relationship. In addition to the direct linkage of this strategy to corporate 
value, part of the impact of diversification on firm value goes through GOR, turning this strategy into less value-destroying insofar as it increases GOR.

The remainder of the paper is organized in four sections. Second 2 sets out our hypotheses. The following section focuses on the research design. In Section 4, our empirical findings are explained. The paper closes with a discussion of our main conclusions, intended contributions, as well as limitations and proposals for future research.

\section{A real options thinking of corporate diversification}

\subsection{Diversification as a trade-off between exercising and creating growth options}

Under the RO logic, a firm's expansion is conceived as the gradual replacement of growth options by assets-in-place (Bowman et al., 1992). Such a conception of the investment process requires the previous existence of a growth option and involves materializing this option by assets-in-place. In the case of diversification, the growth option corresponds to the opportunity to invest in a new/different business and effective participation therein matching the underlying assets-in-place. This simple replacing process is considered by Bernardo and Chowdhry (2002) when they argue that diversified firms hold fewer unexercised growth options than their undiversified counterparts, thus suggesting a negative effect of diversification on GOR.

However, exercising an option to diversify not only implies a stake in a new assets-inplace, but also additional growth options. By exploring and expanding a firm's activity into new businesses, diversification may give rise to new tangible and intangible assets which are the seeds for new investment opportunities (Kasanen, 1993; Kogut, 1991; Kogut and Kulatilaka, 2001; Williamson, 2001). In such instances, exercising growth options translates into new growth opportunities. Moreover, a positive effect on GOR is expected, should this 
diversification generate additional growth options whose value exceeds that of the alreadyexercised option to diversify.

This two-fold impact on a firm's sources of value is captured by the concept of the Expanded Net Present Value (ENPV). On the RO basis, the value created (ENPV) by exercising an option to invest in business “ $i$ ” $\left(C^{*}{ }_{i}\right)$ is defined by the sum of the NPV of cashflows from operating in business $i\left(N P V_{i}\right)$, and the value of new emerging options to invest in businesses " $j$ ” $\left(C_{j}\right)$, with $j=1 \ldots k$ :

$$
E N P V_{i}=C_{i}^{*}=N P V_{i}+\sum C_{j}
$$

A positive ENPV is obtained through either a negative or a positive $N P V$ of cash-flows from assets-in-place. Should the $N P V$ be positive, the value of the exercised option "i” would exceed the value of future growth options “ $j$ ” $\left(C_{i}^{*}>C_{j}\right)$, diversification thus reducing GOR. On the other hand, if NPV is negative, the value of future growth options " $j$ " will exceed that of the exercised option “ $j$ ” $\left(\mathrm{C}_{\mathrm{i}}^{*}<\mathrm{C}_{\mathrm{j}}\right)$, diversification thus increasing GOR.

We further hypothesize that firms would start investing predominantly in exploiting growth options which have a positive NPV, leading to a negative association between diversification and GOR at low levels of diversification. Prior evidence on capital budgeting practices reveals that most managers rely on NPV models, whereas the use of the real options models is limited. ${ }^{2}$ This evidence suggests that managers might generally prefer projects that generate cash flows over those providing options for future growth. Likewise, should

\footnotetext{
${ }^{2}$ Graham and Harvey (2001) investigated the capital budgeting practices of a sample of North American companies and found that $74.9 \%$ of respondents used NPV models, although only $26.6 \%$ of them reported using real options. In Block's (2007), real options models were used by $14.3 \%$ of surveyed U.S. companies. For the case of Canadian firms, Baker et al.(2011) report that 74.6\% of the respondents used DCF models often or always, but that only $10.4 \%$ of used real options as often. More recently, Horn et al. (2015) surveyed CFOs of Scandinavian companies and found that NPV models are used by $74 \%$ of respondents whereas real options models are used by only by $6 \%$.
} 
managers have to select a business in which to diversify from among several offering of similar value to shareholders, they would firstly invest in those with the highest NPV.

At higher levels of diversification, firms may have partly exploited their high NPV investments and would be more likely to invest in negative NPV in exchange for a higher value of emerging options to expand. As a result, in this latter kind of exploring diversifiers, greater diversification will imply higher GOR. Moreover, as the company becomes increasingly diversified, the value of resources and skills is leveraged as these may be redeployed in multiple and different growth options embedded to each of its diversified businesses (Vassolo et al., 2004). Participating in multiple businesses may be the seed of a wider range of investment opportunities by spreading a firm's capabilities across alternative industries (Bowman and Hurry, 1993) and creating a diversified knowledge stock to manage the multiple trajectories of business opportunities arising from uncertainty (Yang, et al., 2014). The stock of accumulated capabilities from broader business activity not only offers the firm preferential access to new opportunities but also improves its sense-making and recognition of current shadow options (Bowman and Hurry, 1993, p. 774).Based on this reasoning, we hypothesize a non-linear relationship between diversification and GOR:

$\mathbf{H}_{1}$ : The impact of the degree of diversification on GOR displays a U-shaped function.

\subsection{The mediating role of GOR in the diversification-value relationship}

Due to the relation between diversification and GOR, the impact of diversification on a firm’s value may not be homogeneous across firms but rather contingent on growth opportunities. Prior literature on the value-diversification relationship has focused on the analysis of the direct impact on benefits and costs (cash flows), which are part of the assetsin-place value. This approach implies omitting the aforementioned relationship between 
diversification and GOR, which may prove to be one of the keys necessary to determine either the value-enhancing or value-destroying effects of diversification.

As pointed out by Amihud and Lev (1981), the critical question is whether stockholders can replicate corporate diversification in their own portfolios. Were investors able to diversify at the same cost as enterprises, corporate diversification would not have an impact on value. Whereas replicating a portfolio of assets-in-place might be feasible (at least in perfect capital markets), replicating a portfolio of growth options seems to be less attainable. It might be argued that an investor could reproduce a diversified firm's growth opportunities by acquiring stocks of single-segment firms of comparable growth opportunities. However, growth options emerge from the interplay of the organization's tangible and intangible assets (Bowman and Hurry, 1993), which could be rooted in different business segments. In this case, putting together the stocks of firms that own these resources and capabilities will not produce the same effect in terms of growth option generation as when directly owning and combining these assets. Additionally, if joint management of multiple businesses has a multiplicative effect on generating new growth options, the value of a growth option portfolio in a diversified firm should be greater than the sum of the values of the growth options embedded in each business considered individually (Vassolo et al., 2004). Consequently, diversification aimed at enhancing GOR may provide the firm with valuable options which individual investors cannot replicate, thus resulting in a diversification premium.

Furthermore, growth options create economic value by generating future decision rights which offer managers the flexibility to redirect company strategy across multiple decisional trajectories and make midcourse decisions as uncertainty unfolds. Growth options enable the firm to keep opportunities open and await fresh information before making a greater or firmer commitment. As a result of this flexibility, corporate diversification may reduce risk and serve 
as a 'strategic insurance' (Raynor, 2002, p. 380-381). Insofar as diversification mainly involves creating those interrelated flexible growth options, it will likely result in a premium, since investors cannot replicate the optimal exercise policy of a diversified firm's portfolio of options. Even in the absence of such a multiplicative effect described earlier, the most an investor can hope to achieve is to replicate the growth options portfolio by acquiring those stocks which contain said options. However, the value of this replicated portfolio should be less than the value of the growth options portfolio of the diversified firm, since optimal joint exercise of a portfolio of options always proves more efficient than optimal independently exercise of each individual option.

These ideas lead us to hypothesize that, in addition to a direct effect of the level of diversification on a firm's value (which numerous studies have dealt with), such a relationship may also be mediated by GOR. Insofar as the diversification value which cannot be achieved through portfolio diversification in capital markets is the value linked to generating and optimal exercise of growth options, a higher GOR is likely to offer a premium. Following on from this, we enunciate our second hypothesis:

$\mathbf{H}_{2}$ : The relationship between diversification and diversification discounts/premiums is mediated by GOR, such that the more that diversification enhances the GOR, the higher the excess value.

\section{Research design: sample selection, model, econometric method, and variables}

\subsection{Sample selection}


We perform our empirical analyses on an unbalanced panel sample of U.S. companies between January $1998^{3}$ and December 2010. To minimize survivorship bias, the sample comprises actives enterprises as well as companies which become inactive or disappear from the sample during the period studied. We use Worldscope Global Database as the principal source of data (annual data both at the industry segment and company level). Industry segment data are computed at the 4-digit-SIC code level. Market data are obtained from Datastream. Finally, we draw macroeconomic data from the Bureau of Economic Analysis, part of the U.S. Department of Commerce ${ }^{4}$.

To make results comparable to previous literature, we use the Berger and Ofek (1995) sample selection criteria. Firstly, we remove firms’ segments with non-positive sales. In addition, we drop firm-year observations with any division in the financial industry (SIC codes 6000-6999). Second, we require sales figures to be at least $\$ 20$ million as well as the availability of data on total capital, total sales, and segment-level sales. To control for possible discrepancies between firm data and segment data disclosed information in databases, the sum of segment sales cannot differ from the firm's reported total sales by more than one percent. Moreover, our estimation methodology, the generalized method of moments (GMM), imposes an additional restriction: the availability of data for at least four consecutive years per firm to test for the lack of second-order residual serial correlation. The final sample consists of 4,053 firm-year observations corresponding to 635 companies.

\footnotetext{
${ }^{3}$ As of December 15, 1997, the new SFAS 131 reporting standard became effective for fiscal years in the United States, replacing the previous SFAS 14. This heralded a change from an "industry approach" to a "management approach", requiring disaggregated information to be reported according to "how management internally evaluates the operating performance of its business units” (Berger and Hann, 2003, p. 164). Our sample starts in 1998 to ensure homogeneity of data. See Berger and Hann (2003) for a study of the impact of SFAS 131 on diversification analyses.

${ }^{4}$ Worldscope contains complete coverage of US companies filing with the Securities Exchange Commission. Worldscope and Datastream are accessed by ThomsonOne, whereas data from the Bureau of Economic Analysis is provided by its official website: http://www.bea.gov/national/index.htm
} 


\subsection{Model}

Figure 1 illustrates the diagram of our three-variable model:

\section{INSERT FIGURE 1 HERE}

As represented in Figure 1, the diversification strategy may influence the firm's value outcomes (excess value) through two paths. On the one hand, a direct effect broadly addressed in prior literature (path $<<\mathrm{c}>>$ ), and on the other, our hypothesized indirect effect (path $<<\mathrm{c}^{\prime}>>$ ) through the GOR mediator (Hypothesis 1). Path $<<\mathrm{a}>>$ captures the link between 'Diversification level’ and GOR, which takes a U-shape as conjectured in our Hypothesis 1, while path $<<\mathrm{b}>>$ illustrates the effect of GOR on 'Excess value'.

According to Baron and Kenny (1986 p. 1176), GOR will act as a mediator if it meets the three following conditions: (i) variations in levels of the independent variable ('diversification level') significantly account for variations in the presumed GOR mediator (path $<<\mathrm{a}>>$ ); (ii) variations in the GOR mediator significantly account for variations in the dependent variable (excess value) (path $<<\mathrm{b}>>$ ); (iii), finally, when paths $<<\mathrm{a}>>$ and $<<\mathrm{b}>>$ are controlled, a previously significant relationship between the independent and dependent variables (path $<<\mathrm{c}>>$ ) is no longer significant (full mediation) or becomes weaker (partial mediation).

\subsubsection{Test of Hypothesis One}

To test our Hypothesis 1 (path $<<a>>$ in Figure 1), we estimate equation (1):

$$
\begin{aligned}
\text { GOR }_{i t}= & \alpha+\beta_{1} \cdot \text { DIVER }_{i t}+\beta_{2} \cdot \text { DIVER }_{\text {it }}^{2}+\beta_{3} \cdot \text { LTA }_{i t}+\beta_{4} \cdot \text { DTA }_{i t}+\beta_{5} \cdot \text { dumINDUSTRY }_{\text {it }}+ \\
& +\beta_{6} \cdot \operatorname{dumYEAR}_{\mathrm{it}}+\eta_{\mathrm{i}}+v_{\mathrm{it}}
\end{aligned}
$$


where $i$ identifies each firm, $t$ indicates the year of observation (from 1 to 13), $\alpha$ and $\beta_{p}$ are the coefficients to be estimated, $\eta_{i}$ represents the firm-specific effect, and $v_{i t}$ is the random disturbance for each observation. The dependent variable (growth options relevance, GOR) is alternatively estimated by the variables of return skewness (denoted by skewness) and residual GO (denoted by residualGO).

Prior research, such as Duffee (1995), has shown that stock returns are generally positively skewed, partly due to the 'option-like' properties caused by the limited liability of equity (Merton, 1974), which offers unlimited upside potential with losses limited to the investment cost. This already positive skewness from limited liability is augmented in the case of firms that have a high fraction of their value in the form of growth options (Andrés et al., 2006; Haannappel and Smit, 2007). Given this skewed distribution of (compound) option returns, stocks with more abundant growth options are likely to have a higher positive skewness.

The variable of skewness is calculated by Fisher's skewness coefficient using each firm's daily returns for the observation year. ResidualGO is estimated in the spirit of Brown and Perry (1994) and Servaes and Tamayo (2013), by regressing market-to-book assets ratio (MBAR) against a firm's excess value (ExcessValue) and taking the residuals of this regression as the halo-removed proxy for growth opportunities. Additionally, and as a robustness control, we re-estimate the model with the widely-used variable of market-to-book assets ratio (MBAR) (e.g. Adam and Goyal, 2008; Chen et al., 2016), which is computed as in Adam and Goyal (2008). ${ }^{5}$

\footnotetext{
${ }^{5}$ In the cases of the ResidualGO and MBAR, we exclude non-positive residuals since they are not a meaningful measure of growth opportunities (Adam and Goyal, 2008).
} 
The explanatory variable is the degree of diversification (DIVER), which we approximate by three different measures commonly used in diversification literature in order to test the robustness of our empirical findings: the number of businesses, the Herfindahl index (Hirschman, 1964), and the entropy measure (Jacquemin and Berry, 1979). The former is the simple count of the number of segments at the 4-digit SIC code level (numsegments). As usual, the Herfindahl index (HERF) is defined by:

$$
\operatorname{HERF}=1 \sum_{s=1}^{\mathrm{n}} \mathrm{P}_{\mathrm{s}}^{2}
$$

where ' $n$ ' is the number of a firm's segments (at the 4-digit SIC code level), and ' $P_{s}$ ' the proportion of the firm's sales from business ' $s$ '. Unisegment firms will show a Herfindahl index equal to zero, and the closer this index is to one, the higher the level of diversification.

The entropy measure (TotalEntropy) considers diversification across different levels of industry aggregation and within them. The higher the total entropy, the greater the diversification (this index has no upper boundary). The value of total entropy is obtained as follows:

$$
\text { Total Entropy }=\sum_{\mathrm{s}=1}^{\mathrm{n}} \mathrm{P}_{\mathrm{s}} * \ln \left(\frac{1}{\mathrm{P}_{\mathrm{s}}}\right)
$$

where ' $P_{s}$ ' is the proportion of a firm's sales in business ' $s$ ' for a corporation with ' $n$ ' different 4-digit SIC segments.

To ensure comparability of our results with prior literature, in equation (1) we control for size (Andrés et al., 2005), leverage (Myers, 1977), industry, and year. Size (LTA) is estimated by the natural logarithm of the book value of total assets. Leverage (DTA) is measured by the total ratio debt over total assets. We include dummy variables to control for the major groups 
of industries ${ }^{6}$ (dumINDUSTRY) and dummies to control for the year effect (dumYEAR).

Finally, we control for unobserved individual heterogeneity by including $\eta_{\mathrm{i}}$.

\subsubsection{Test of Hypothesis Two}

To test our Hypothesis 2, which predicts that GOR mediates the relationship between diversification and the firm's excess value, we evaluate conditions proposed by Baron and Kenny (1986) already mentioned, which would correspond to estimating equations (4) and

(5) for comparing paths $\left\langle<\mathrm{c}>>\right.$ and $\left\langle<\mathrm{c}{ }^{\prime}>>(<<\mathrm{a}>>+<<\mathrm{b}>>)\right.$.

Path c ExcessValue $_{i t}=\alpha+\beta_{1} \cdot$ DIVER $_{\text {it }}+\beta_{2} \cdot$ EBITsales $_{\text {it }}+\beta_{3} \cdot$ CAPEXsales $_{i t}+\beta_{4} \cdot$ LDTA $_{\text {it }}$

$$
\begin{aligned}
& +\beta_{5} \cdot \mathrm{LTA}_{\mathrm{it}}+\beta_{6} \cdot \mathrm{LTA}_{\mathrm{it}}+\beta_{7} \cdot \text { dumINDUSTRY }_{\mathrm{it}}+\beta_{8} \cdot \text { dumYEAR }_{\mathrm{it}} \\
& +\eta_{\mathrm{i}}+v_{\mathrm{it}}
\end{aligned}
$$

Paths b

ExcessValue $_{i t}=\alpha+\beta_{1} \cdot$ GOR $_{\text {it }}+\beta_{2} \cdot$ DIVER $_{\text {it }}+\beta_{3} \cdot$ EBITsales $_{\text {it }}+\beta_{4} \cdot$ CAPEXsales $_{\text {it }}$ and c'

$$
\begin{aligned}
& +\beta_{5} \cdot \text { LDTA }_{i t}+\beta_{6} \cdot \text { LTA }_{i t}+\beta_{7} \cdot \text { LTA2 }_{i t}+\beta_{8} \cdot \text { dumINDUSTRY }_{i t} \\
& +\beta_{9} \cdot \operatorname{dumYEAR} \\
& \text { it }
\end{aligned}
$$

where $i$ identifies each firm, $t$ indicates the year of observation (from 1 to 13), $\alpha$ and $\beta_{p}$ are the coefficients to be estimated, $\eta_{i}$ is the firm-specific effect, and $v_{i t}$ is the random disturbance for each observation. The dependent variable in equations (4) and (5) is excess value (ExcessValue), as developed by Berger and Ofek (1995), and is defined as the natural log of a firm's market value ${ }^{7}$ to its imputed value.

\footnotetext{
${ }^{6}$ Major groups of industries as defined by the U.S. Department of Labor. The official website provides the matching of these major groups to the 2-digit SIC code classification:

http://www.osha.gov/pls/imis/sic_manual.html. The industry dummy $j(j=1, \ldots, 8)$ takes 1 if the firm reports some segment operating in industry $j$ and zero otherwise.

${ }^{7}$ So as to compare with most previous literature, we compute a firm's market value $(M V)$ as the sum of market value of equity, long-term, short-tem debt, and preferred stock (Campa and Kedia, 2002).
} 
The firm's imputed value (IV) is calculated as the sum of the imputed values of its divisions. Each segment's imputed value is computed by multiplying its segment sales $\left(S_{s}\right)$ by the annual median sales multiplier (the median ratio of a firm's value to total sales), $I S M_{s}$, of all single-segment firms operating in the same and most restrictive SIC group which comprises at least five unisegment firms (4-digit, 3-digit or 2-digit SIC code levels):

$$
\mathrm{IV}=\sum_{\mathrm{s}=1}^{\mathrm{n}} \mathrm{S}_{\mathrm{s}} * \mathrm{ISM}_{\mathrm{s}}
$$

$S_{s}$ and $I S M_{s}$ denoting sales and imputed sales multipliers of segment 's', respectively, and $n$ the number of a firm's divisions $(s=1, \ldots, n)$.

Finally, the excess value is obtained by dividing the firm's value by its imputed value $(M V / I V)$, and then taking the natural logarithm of this ratio. If the excess value is negative, a discount will emerge. In contrast, a positive excess value will imply that the diversifier trades at a premium over its single-segment counterparts, a diversification strategy thus contributing towards enhancing a firm's value.

The explanatory variables are DIVER in equation (4), and DIVER and GOR in equation (5). If GOR were to play a mediating role, the statistical significance of the coefficient of the variable DIVER would be reduced (partial mediation) or disappear (full mediation) in equation (5) compared to that in equation (4) in which the mediating variable was not controlled for.

In both equations, we control for factors which are likely to affect ExcessValue and are not related to the diversification decision. Following prior research (Berger and Ofek, 1995; Campa and Kedia, 2002; Santaló and Becerra, 2008), we control for profitability, level of current investment, financial leverage, firm size, industry (dumINDUSTRY), and year effect (dumYEAR). Profitability is computed by the EBIT to sales ratio (EBITsales), and the level of 
This work is licensed under a Creative Commons Attribution-NonCommercial-NoDerivatives 4.0 International License. This is a preprint draft of a paper accepted (17 October 2016) for publication in International Review of Financial Analysis 48 (2016) 261-271. The published version is available at: http://dx.doi.org/10.1016/j.irfa.2016.10.007

investment by capital expenditures to total sales ratio (CAPEXsales). Financial leverage is estimated by the ratio of long-term debt to total assets (LDTA), and firm size is approximated by the natural logarithm of the book value of total assets (LTA). Furthermore, we include the square of LTA (LTA2) to control for a possible non-linear effect of firm size on firm value (Campa and Kedia, 2002). As in equation (1), we control for the firm-specific effect $\left(\eta_{i}\right)$.

\subsection{Econometric approach and robustness tests}

All computations in this paper are carried out using STATA 11.0. All equations are estimated by using panel data methodology to address two concerns: the existence of unobservable individual heterogeneity and endogeneity. The former refers to certain time constant firm-specific characteristics (such as the firm's culture or corporate strategy), which determine a firm's behaviour and also explain the dependent variable in equations (1), (4) and (5). Secondly, a key concern in diversification models is endogeneity (Campa and Kedia, 2002; Villalonga, 2004). The causal relation between diversification and GOR, and between diversification and excess value may not only run in the hypothesized direction, but also in both directions. To address this problem, following a wide stream of Finance literature (AlMaskati et al., 2015; Bonaimé et al., 2014; Fuente and Velasco, 2015; La Rocca et al., 2009, to name but a few examples), we use the two-step system generalized method of moments (GMM) proposed by Blundell and Bond $(1998)^{8}$. System GMM avoids the weak instrument problem attributed to the first difference GMM estimator (Alonso-Borrego and Arellano, 1999). GMM employs the lags of explanatory variables as instruments. In this way, our estimation technique ensures a set of internal instruments contained within the panel, thus avoiding the need to resort to external instruments (Wintoki et al., 2012). Moreover, GMM is

\footnotetext{
${ }^{8}$ We use the xtabond2 command in STATA to compute the two-step system GMM estimator.
} 
seen to involve gains in efficiency compared to other instrumental techniques as a result of combining multiple orthogonality conditions (Almeida et al., 2010).

Below all the estimations, we include two model specification tests for GMM estimation validity. The GMM estimator is based on two assumptions: absence of second-order serial correlation and lack of correlation between the instruments and the residuals. First, Arellano and Bond's (1991) $m_{2}$ statistic $^{9}$ tests the absence of second degree serial correlations in the first-difference residuals. Since the GMM estimator uses lags as instruments under the assumption of white noise errors, it would lose its consistency if the errors were serially correlated (Arellano and Bond, 1991). Secondly, the Hansen J-test of overidentifying restrictions (Hansen, 1982) assesses the instrument exogeneity assumption. The null hypothesis is the joint validity of all the instruments.

We conduct a number of robustness tests. First, we check whether the U-form relation estimated in equation (1) is robust to the choice of industry classification. We compute the number of firm segments (numsegments_3d and numsegments_2d) and the Herfindahl index (HERF_3d and HERF_2d) with 3-digit and 2-digit SIC code business segment data. Second, to assess further the validity of this U-shaped relationship between DIVER and GOR, we perform Sasabuchi's (1980) t-test $^{10}$. Sasabuchi's test checks the composite null hypothesis that the relationship increases on the left hand side of the interval and/or decreases on the right hand side $\left(\mathrm{H}_{0}\right.$ : Monotone or inverse $\mathrm{U}$ shape; $\mathrm{H}_{1}$ : $\mathrm{U}$ shape). We also estimate the extreme point of the curve.

\footnotetext{
${ }^{9}$ We also include the $m_{1}$ statistic to test the first-order residual serial correlation, although the existence of this correlation does not invalidate the results.

${ }^{10}$ This test was computed using the ado-file utest for STATA developed by Lind and Mehlum, available at http://econpapers.repec.org/software/bocbocode/s456874.htm
} 
In testing the mediating effect, any previous significant relationship between DIVER and ExcessValue should lose significance when considering GOR. If the effect of DIVER on ExcessValue (equation (4)) does not decrease to insignificant in equation (5) after controlling for GOR, full mediation is not supported, although partial mediation may still hold. In this case, Sobel's test (Sobel, 1982) would be conducted to determine the significance of the indirect effect of DIVER on ExcessValue through the GOR mediator by testing the null hypothesis of no difference between the direct effect (path $\langle<\mathrm{C}>>$ ) and the indirect effect $\left(\text { path }<<\mathrm{c}^{\prime}>>\right)^{11}$.

Additional robustness analyses re-estimate the models by dropping the 'extreme' excess values from the sample. Berger and Ofek (1995) define these as observations whose excess value is above 1.386 or below -1.386 .

\section{Results}

\subsection{Descriptive statistics}

Table 1A provides the descriptive statistics of the variables for the full sample. Overall, sample firms show a low diversifying profile (1.88 business segments on average), the number of segments ranging between 1 and 5 . The number of SIC code digits (2, 3 or 4$)$ at which the number of segments are determined does not give rise to perceptible differences in summary diversification profiles. We notice the presence of an average premium (mean=0.0990), which is higher in the subsample of unisegment firms (mean=0.1393) than in the diversified firm subsample (mean=0.0788). We find that the growth opportunities relevance as measured by $M B A R$ mean is 2.2705 (median=1.5422). This value drops to 2.0148 (median=1.2389) after removing the firm's excess value effect in residual GO

\footnotetext{
${ }^{11}$ Sobel's test is obtained by using the sgmediation command in STATA.
} 
estimation. The mean of return skewness is 0.4810 (median=0.3694). Table $1 \mathrm{~B}$ displays the descriptive statistics disaggregated by the firms’ diversification status: unisegment firm subsample and diversified firm subsample.

\section{INSERT TABLE 1A HERE}

\section{INSERT TABLE 1B HERE}

\subsection{The interaction between DIVER and GOR (path $<<a>>$ )}

Table 2 reports the estimation results of equation (1) in which we test the impact of the degree of diversification on the firm's growth options portfolio. We find strong evidence of a U-form relationship with the growth options proxies. As shown in the first column of Table 2 , the main effect of numsegments is negative and statistically significant $\left(\beta_{1}=-0.5403, p\right.$ value $=0.056)$ and its squared term is positive and significant $\left(\beta_{2}=0.0970, p\right.$-value $\left.=0.077\right)$. This U-shape relation remains, and with even stronger statistical significance, across the alternative proxies for GOR, except with residualGO, when diversification is measured by $H E R F$. Our results are also robust to the different measures to capture diversification and to the industry classification choice ${ }^{12}$. Additionally, to verify the validity of this curvilinear relationship, we perform Sasabuchi’s test. Consistent with prior estimations, Sasabuchi’s test provides further evidence supporting the U-effect at the $1 \%$ level across almost all the alternative estimations (the only exception being for skewness on TotalEntropy).

\section{INSERT TABLE 2 HERE}

As hypothesized, at lower diversification levels investing in a new business has a negative impact on GOR, reflecting the replacement of growth opportunities by assets-in-

\footnotetext{
${ }^{12}$ Number of segments and Herfindahl index computed at the 3-digit and 2-digit SIC code level (numsegments_3d, numsegments_2d, HERF_3d and HERF_2d, respectively. Most results remain similar. Results are available upon request from the corresponding author.
} 
place. However, the company reaches a minimum from which it may have been able to accumulate enough experience and develop superior capabilities, turning diversification into a source of growth options. This critical point from which the relationship turns round and becomes positive appears around numsegments*=2 (HERF* around 0.4$)$ for our sample.

Hansen and $m_{2}$ tests confirm the validity of our GMM estimations. The Hansen $J$ statistic fails to reject the null hypothesis of absence of correlation between the instruments and the residuals, thus indicating the instruments are valid. The $m_{2}$ statistic does not reject the null hypothesis of no second-order residual serial correlation. The Wald test, significant above the $1 \%$ level, confirms the joint significance of the variables in the models.

\subsection{Analyses of the mediating role of GOR on the diversification-value relationship}

In columns (1) to (3) in Table 3, we replicate the diversification model estimated in prior literature. In line with the main stream of research, our sample shows a diversification discount, statistically significant above the $1 \%$ level. This diversification discount persists across the alternative measures of diversification.

\section{INSERT TABLE 3 HERE}

Apart from this direct effect of diversification of firm's value, our Hypothesis 2states that this relationship may also be mediated by GOR (indirect effect). We apply Baron and Kenny's conditions to test whether the GOR affects diversification value outcomes, and whether the effect of the level of diversification on ExcessValue becomes weaker or loses its statistical significance once growth opportunities are included in the model to test for the mediating effect. Columns (4) to (12) in Table 3 display estimation results.

Firstly, we find a positive and strongly significant statistical relationship ( $p$-value $=0.000$ ) between the proxies for GOR (either skewness, residualGO or MBAR) and ExcessValue, 
thereby confirming the significance of path $<<\mathrm{b}>>$. We find that the value of the firm's set of growth opportunities significantly contributes towards the relative value of diversifiers over their undiversified counterparts. We report evidence that the higher the relevance of growth opportunities, the higher the ExcessValue. This finding is consistent with prior literature such as Ferris et al. (2002).

Secondly, our results also reveal strong evidence of partial mediation. When GOR proxies are introduced in the regressions, the diversification coefficients show lower statistical significance, or even lose it. The clearest evidence is obtained when growth opportunities are measured by the halo-removed proxy residualGO (columns (5), (8) and (11)), and in models involving skewness and numsegments (column (4)) or MBAR and HERF (column (9)). In these five cases (out of nine alternative robustness regressions), the diversification variable drops to non-significant and thus, might even support full mediation. All these empirical findings taken together support some form of mediation of GOR in the relationship between ExcessValue and the degree of diversification. As the statistical significance of the diversification variables does not disappear completely in all cases, these findings support the idea that GOR is a partial mediator between diversification and ExcessValue, and that additional mediators might be operating in said relationship. Growth opportunities may drive an indirect effect of diversification on ExcessValue, making this corporate strategy more value-enhancing insofar as it serves as a platform for further growth options.

\section{INSERT TABLE 4 HERE}

Finally, we conduct the Sobel test (see Table 4) as an additional robustness analysis. This test also supports the indirect effect of diversification on ExcessValue through all proxies for GOR, apart from skewness. Results are statistically significant above the $1 \%$ level, except in 
the analyses with residualGO, in which significance is lower. When significant, the proportion of total effect mediated by growth options proxies ranges between 0.3139 and 0.3569 .

All the findings detailed in this section are robust to the exclusion from the sample of the ‘extreme’ Excess Value (below -1.386 or above 1.386) ${ }^{13}$. In all regressions, both the Hansen and $m_{2}$ test support the validity of the GMM estimations. The Wald test confirms the joint significance of the variables.

\section{Summary and conclusions}

We join the controversial diversification-value linkage debate. This paper sheds further light on the role growth options play in said relationship based on a dataset of U.S. companies between 1998 and 2010. We find evidence of a U-shaped relationship between a firm’s diversification and its growth options. At low levels of diversification, diversification has a negative effect on GOR, as entering in new businesses mainly implies replacing growth options with assets-in-place. However, as the firm broadens its diversification scope it reaches an inflexion point from which the relationship between GOR and diversification flips and turns positive (even non-linearly) as a result of diversification becoming a source of additional growth options. Moreover, our empirical findings reveal that growth opportunities partially mediate the effect of diversification on a firm's value, this strategy being less valuedestroying when it boosts creation of new growth options to a greater extent than exercising existing ones.

Our paper contributes to the current literature in a number of ways. First, this paper reexamines the nature of corporate diversification from an $\mathrm{RO}$ approach. Certain managerial

${ }^{13}$ Results are available upon request from the corresponding author. 
investment decisions which may seem counter-valuable for a firm’s assets-in-place can, however, be justified in terms of their options value. We also provide a rational explanation for the apparently contradictory relation between diversification and growth options. It has been argued that diversified firms have fewer growth opportunities than single segment firms. The reason may be ex-ante: diversified firms had poorer growth opportunities before they diversify and this strategy is the mechanism they choose for seeking fresh sources of expansion (Holder and Zhao, 2015; Hyland and Diltz, 2002; Stowe and Xing, 2006); or expost: diversification implies exercising profitable current growth options by replacing them with their underlying assets (Bernardo and Chowdhry, 2002). In the first case, it seems that corporate diversification is a kind of an inefficient (or at least sluggish) source of growth options, whereas in the second case, corporate diversification seems to immediately deplete growth options. From an RO perspective, we contend that both arguments may be right and even compatible.

Secondly, we provide evidence regarding the partial mediating role of growth options in the diversification-value relationship, adding a further piece to the 'diversification puzzle' which ties in with the firm-specific characteristics suggested by Campa and Kedia (2002) or Rajan et al. (2000) as determinants of the diversification discounts/premiums. Our empirical findings are based on alternative proxies for the relevance of growth opportunities which are grounded on the RO approach and might help to overcome a number of disadvantages found in traditional measures.

By way of a third contribution, we offer updated evidence on a post-1997 sample, after implementation of the new SFAS 131 reporting standard in the U.S. which is seen to provide more disaggregated information on segment data (Berger and Hann, 2000). We also tie in with recent streams of research which underscore the endogeneity linked to the 
diversification decision and we control for it in all regressions by using an instrumental estimation technique (GMM).

From a practical point of view, our study also has major implications for practitioners. We encourage financial analysts and scholars alike to examine diversification through the RO lens, which enlarges the focus on distinguishing between exploiting and exploring investment opportunities as a way to identify their different effect on value creation. Our findings also reveal to managers that they should implement those diversification strategies that are nonreplicable by stockholders on their own. Finally, we analyze some limitations that might open up future research lines. First, our sample only contains firms from the United States. We are aware of the need to replicate our study on an international sample of companies and check the consistency of our results ${ }^{14}$. In addition, the search for additional moderating and mediating factors in the diversification-performance relationship might also be tackled. Diversification may be a value-destroying strategy under certain conditions but not under others. Our study reveals that this corporate strategy has a positive impact on firm value in those enterprises with a diversification that is primarily geared towards generating new growth options. How firms deal with them when implementing diversification strategy may give rise to different diversification patterns which, in turn, may spark different value outcomes.

\section{References}

Adam, T., \& Goyal, V.K. (2008). The Investment Opportunity Set and its Proxy Variables.

The Journal of Financial Research, 31(1), 41-63.

\footnotetext{
${ }^{14}$ Barnes and Hardie-Brown (2006), Chen and Ho (2000), or Lins and Servaes (1999), among others, have provided international evidence on the diversification-value linkage which would be extended by considering the mediation role played by growth options.
} 
Al-Maskati, N., Bate, A. \& Bhabra, G. (2015). Diversification, corporate governance and firm value in small markets: evidence from New Zealand. Accounting and Finance, 55(3), $627-657$.

Almeida, H., Campello, M. \& Galvao, A. (2010). Measurement errors in investment equations. The Review of Financial Studies, 23(9), 3279-3328.

Alonso-Borrego, C., \& Arellano, M. (1999). Symmetrically normalized instrumental-variable estimation using panel data. Journal of Business \& Economic Statistics, 17(1), 36-49.

Amihud, Y. \& Lev, B. (1981). Risk reduction as a managerial motive for conglomerate mergers. Bell Journal of Economics, 12(2), 605-617.

Andrés, P., Azofra, V. \& Fuente, G. (2005). Real options as a component of the market value of stocks: evidence from the Spanish Stock Market. Applied Economics, 37(14), 16731691.

Andrés, P., Azofra, V. \& Fuente, G. (2006). The real options component of firm market value: The case of the technological corporation. Journal of Business Finance \& Accounting, 33(1-2), 203-219.

Arellano, M. \& Bond, S. (1991). Some tests of specification for panel data: Monte Carlo evidence and an application to employment equations. The Review of Economic Studies, 58(2), 277-297.

Baker, H.K., Dutta, S., \& Saadi, S. (2011). Corporate Finance Practices in Canada: Where Do We Stand?. Multinational Finance Journal, 15 (3/4), 157-192.

Barnes, E. \& Hardie-Brown, G. (2006). The diversification puzzle: Revisiting the value impact of diversification for UK firms. Journal of Business Finance \& Accounting, 33(9), 1508-1534.

Baron, R. \& Kenny, D. (1986). The moderator-mediator variable distinction in social psychological research: conceptual, strategic and statistical considerations. Journal of 
Personality and Social Psychology, 51(6), 1173-1182.

Berger, P.G. \& Hann, R. (2003). The impact of SFAS No. 131 on information and monitoring. Journal of Accounting Research, 41(2), 163-223.

Berger, P.G. \& Ofek, E. (1995). Diversification's effect on firm value. Journal of Financial Economics, 37(1), 39-65.

Bernardo, A. \& Chowdhry, B. (2002). Resources, real options, and corporate strategy. Journal of Financial Economics, 63(1), 211-234.

Block, S. (2007). Are "real options” actually used in the real world? The Engineering Economist, 52(3), 255-267.

Blundell, R. \& Bond, S. (1998). Initial conditions and moment restrictions in dynamic panel data models. Journal of Econometrics, 87(1), 115-143.

Bonaimé, A., Öztekin, Ö \& Warr, R. (2014). Capital structure, equity mispricing, and stock repurchases. Journal of Corporate Finance, 26, 182-200.

Bowman, E., Hurry, D. \& Miller, A. (1992). Calls on high technology: Japanese exploration of venture capital investments in the United States. Strategic Management Journal, 13(2), 85-101.

Bowman, E.H. \& Hurry, D. (1993). Strategy through the option lens: an integrated view of resource investments and the incremental-choice process. The Academy of Management Review, 18(4), 760-782.

Brown, B. \& Perry, S. (1994). Removing the financial performance halo from Fortune's ‘most admired’ companies. Academy of Management Journal, 37(5), 1347-1359.

Campa, J.M. \& Kedia, S. (2002). Explaining the diversification discount. The Journal of Finance, 57(4), 1731-1762.

Chen, S. \& Ho, W. (2000). Corporate diversification, ownership structure, and firm value: The Singapore evidence. International Review of Financial Analysis, 9(3), 315-326. 
Chen, J., Jia, T. \& Sun, P. (2016). Real option component of cash holdings, business cycle, and stock returns. International Review of Financial Analysis, 45, 97-106.

Dhaliwal, D., Heninger, W. \& Hughes, K. (1999). The investment opportunity set and capitalization versus expensing methods of accounting choice. Accounting and Finance, 39(2): 151-175.

Duffee, G. (1995). Stock returns and volatility a firm-level analysis. Journal of Financial Economics, 37(3), 399-420.

Ferris, S.P., Sen, N., Lim, C.Y. \& Yeo, G. (2002). Corporate focus versus diversification: the role of growth opportunities and cash flow. Journal of International Financial Markets Institutions and Money, 12(3), 231-252.

Fuente, G. \& Velasco, P. (2015). The effect of the financial crisis on the value of corporate diversification in Spanish firms. Spanish Journal of Finance and Accounting, 44(1), 1-23.

Graham, J. R., \& Harvey, C. R. (2001). The theory and practice of corporate finance:

Evidence from the field. Journal of Financial Economics, 60(2-3), 187-243.

Haanappel, H. \& Smit, H. (2007). Return distributions of strategic growth options. Annals of Operations Research, 151(1), 57-80.

Hansen, L. P. (1982). Large sample properties of generalized method of moments estimators. Econometrica, 50(4), 1029-1054.

Hirschman, A. (1964). The paternity of an index. American Economic Review, 54(5), 761770.

Holder, M. \& Zhao, A. (2015). Value exploration and materialization in diversification strategies. Review of Quantitative Finance and Accounting, 45(1), 175-213.

Horn, A., Kjærland, F., Molnár, P., \& Steen B.W. (2015). The use of real option theory in Scandinavia's largest companies. International Review of Financial Analysis, 41 (2015) 74-81. 
Hyland, D. \& Diltz, D. (2002). Why firms diversify: An empirical examination. Financial Management, 31(1), 51-81.

Jacquemin, A.P. \& Berry, C.H. (1979). Entropy measure of diversification and corporate growth. The Journal of Industrial Economics, 27(4), 359-369.

Kasanen, E. (1993). Creating value by spawning investment opportunities. Financial Management, 22(3), 251-258.

Kogut, B. (1991). Joint ventures and the options to expand and acquire. Management Science, 37(1), 19-33.

Kogut, B. \& Kulatilaka, N. (2001). Capabilities as real options. Organization Science, 12(6), 744-758.

Lang, L., Ofek, E. \& Stulz, R. (1996). Leverage, investment, and firm growth. Journal of Financial Economics, 40(1), 3-29.

La Rocca, M., La Rocca, T., Gerace, D. \& Smark, C. (2009). Effect of diversification on capital structure. Accounting and Finance, 49(4), 799-826.

Lins, K. \& Servaes, H. (1999). International evidence on the value of corporate diversification. The Journal of Finance, 54(6), 2215-2239.

Mansi, S. A. \& Reeb, D. (2002). Corporate diversification: what gets discounted? The Journal of Finance, 57(5), 2167-2183.

Merton, R.C. (1974). On the pricing of corporate debt: the risk structure of interest rates. The Journal of Finance, 29(2), 449-470.

Myers, S.C. (1977). Determinants of corporate borrowing. Journal of Financial Economics, 5(2), 147-175.

Rajan, R., Servaes, H. \& Zingales, L. (2000). The cost of diversity: the diversification discount and inefficient investment. The Journal of Finance, 55(1), 35-80. 
Raynor, M.E. (2002). Diversification as real options and the implications of firm-specific risk and performance. The Engineering Economist, 47(4), 371-389.

Santaló, J. \& Becerra, M. (2008). Competition from specialized firms and the diversificationperformance linkage. The Journal of Finance, 63(2), 851-883.

Sasabuchi, S. (1980). A test of a multivariate normal mean with composite hypotheses determined by linear inequalities. Biometrica, 67(2), 429-439.

Servaes, H. \& Tamayo, A. (2013). The impact of corporate social responsibility on firm value: the role of customer awareness. Management Science, 59(5), 1045-1061.

Sobel, M.E. (1982). Asymptotic confidence intervals for indirect effects in structural equation models, in: Leinhardt, S., ed., Sociological Methodology, American Sociological Association.

Stowe, J. \& Xing, X. (2006). Can growth opportunities explain the diversification discount?, Journal of Corporate Finance, 12(4), 783-796.

Vassolo, R., Anand, J. \& Folta, T.B. (2004). Non-additivity in portfolios of exploration activities: a real options-based analysis of equity alliances in biotechnology. Strategic Management Journal, 25(11), 1045-1061.

Villalonga, B. (2004). Does diversification cause the ‘diversification discount'?, Financial Management, 33(2), 5-27.

Williamson, P. (2001). Strategy as options on the future, in: Cusumano, M., C. and Markides, ed., Strategic Thinking for the Next Economy, MIT Sloan Management Review, Ed. Jossey-Bass A Wiley Company, Cambridge, MA, chapter7, 157-178.

Wintoki, B., Linck, J. \& Netter, J. (2012). Endogeneity and the dynamics of internal corporate governance. Journal of Financial Economics, 105(3), 581-606.

Yang, Y., Narayanan, V. \& De Carolis, D. (2014). The relationship between portfolio diversification and firm value: The evidence from corporate venture capital activity. 
This work is licensed under a Creative Commons Attribution-NonCommercial-NoDerivatives 4.0 International License. This is a preprint draft of a paper accepted (17 October 2016) for publication in International Review of Financial Analysis 48 (2016) 261-271. The published version is available at: http://dx.doi.org/10.1016/j.irfa.2016.10.007

Strategic Management Journal, 35(13), 1993-2011. 


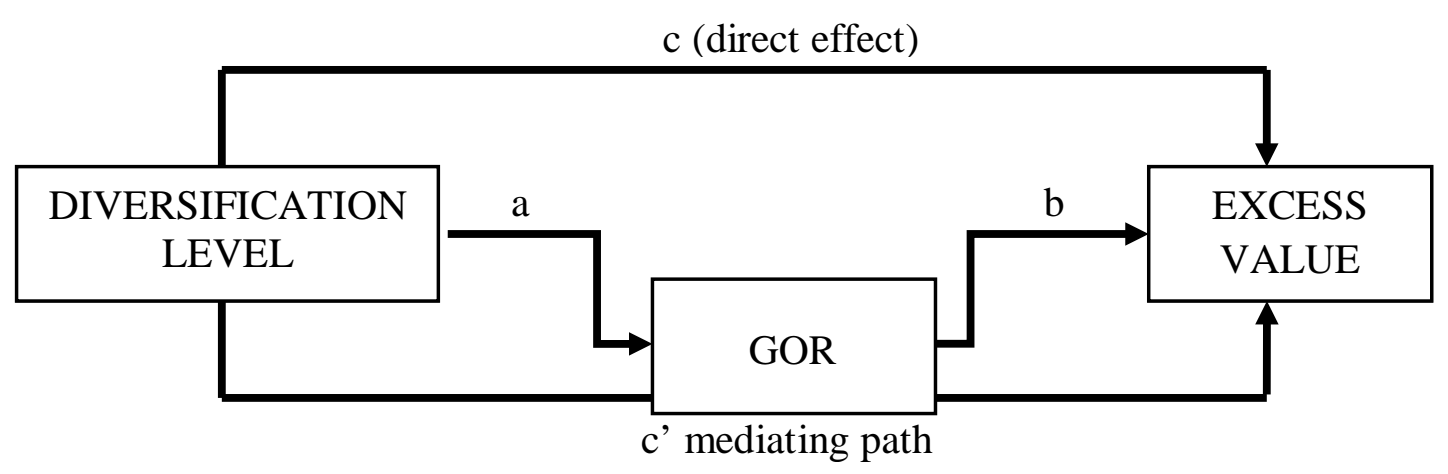

Figure 1. Causal chain of our proposed mediated model]. This diagram represents the causal chain of the three-variable model we propose in our paper. As represented in the figure, the influence of the corporate diversification strategy on the ExcessValue may go through two different paths: a direct effect (path $<<\mathrm{c}>>$ ) and an indirect effect (path $<<\mathrm{c}^{\prime}>>$ ) through the GOR mediator. 


\section{Table 1A}

Summary statistics of variables for the full sample (1998-2010).

This table displays descriptive statistics of the variables involved in our models for the final sample of 4,053 firm-year observations. Excess_value is the measure developed by Berger and Ofek (1995) to assess the value created by diversifying. Skewness (return skewness), residualGO (halo-removed proxy for growth opportunities based on the residuals of the regression of MBAR on Excess_value) and MBAR (the market to book assets ratio) are the three different proxies for growth opportunities relevance (GOR). numsegments (number of business segments at the 4-digit SIC code level), numsegments_3d (number of business segments at the 3-digit SIC code level), numsegments_2d (number of business segments at the 2-digit SIC code level), HERF (the Herfindahl index at the 4-digit SIC code level), HERF_3d (the Herfindahl index at the 3-digit SIC code level), HERF_2d (the Herfindahl index at the 2-digit SIC code level) and TotalEntropy (the Entropy index) are alternative measures for the level of diversification. Control variables: LTA (size), EBITsales (profitability), CAPEXsales (level of investment in current operations), DTA and LDTA (financial leverage).

\begin{tabular}{|c|c|c|c|c|c|c|c|c|}
\hline Variable & $\mathbf{N}$ & Mean & Median & $\begin{array}{l}\text { Standard } \\
\text { deviation }\end{array}$ & Min. & Max. & $\begin{array}{c}1^{\text {st }} \\
\text { quartile }\end{array}$ & $\begin{array}{c}3^{\text {rd }} \\
\text { quartile }\end{array}$ \\
\hline ExcessValue & 4053 & 0.0990 & 0.0670 & 0.8818 & -4.2895 & 4.9299 & -0.4132 & 0.6227 \\
\hline \multicolumn{9}{|l|}{$\begin{array}{l}\text { Proxies for growth } \\
\text { opportunities }\end{array}$} \\
\hline skewness & 3277 & 0.4810 & 0.3694 & 1.7084 & -19.0788 & 17.4944 & -0.1269 & 0.9337 \\
\hline residualGO & 876 & 2.0148 & 1.2389 & 2.5720 & 0.0018 & 22.7588 & 0.6225 & 2.3354 \\
\hline MBAR & 4053 & 2.2705 & 1.5422 & 2.3336 & 0.1391 & 34.0760 & 1.0814 & 2.4981 \\
\hline \multicolumn{9}{|l|}{$\begin{array}{c}\text { Diversification } \\
\text { indexes }\end{array}$} \\
\hline numsegments & 4053 & 1.8831 & 2 & 0.7909 & 1 & 5 & 1 & 2 \\
\hline numsegments_3d & 4053 & 1.8236 & 2 & 0.7436 & 1 & 5 & 1 & 2 \\
\hline numsegments_2d & 4053 & 1.7496 & 2 & 0.6725 & 1 & 5 & 1 & 2 \\
\hline HERF & 4053 & 0.2417 & 0.2150 & 0.2251 & 0 & 0.7833 & 0 & 0.4615 \\
\hline HERF_3d & 4053 & 0.2292 & 0.1912 & 0.2204 & 0 & 0.7833 & 0 & 0.4448 \\
\hline HERF_2d & 4053 & 0.2123 & 0.1696 & 0.2102 & 0 & 0.7833 & 0 & 0.4224 \\
\hline TotalEntropy & 4053 & 0.3854 & 0.3753 & 0.3568 & 0 & 1.5681 & 0 & 0.6662 \\
\hline \multicolumn{9}{|l|}{ Control variables } \\
\hline LTA & 4053 & 6.6710 & 6.6198 & 2.0608 & 1.7710 & 12.5269 & 5.0447 & 8.2406 \\
\hline EBIT/sales & 4053 & 0.0610 & 0.0809 & 0.2597 & -6.6030 & 0.7455 & 0.0303 & 0.1436 \\
\hline CAPEX/sales & 4053 & 0.0706 & 0.0342 & 0.1596 & 0 & 4.0955 & 0.0188 & 0.0668 \\
\hline DTA & 4053 & 0.2312 & 0.2269 & 0.1726 & 0 & 0.8794 & 0.0816 & 0.3434 \\
\hline LDTA & 4053 & 0.1901 & 0.1736 & 0.1615 & 0 & 0.8362 & 0.0443 & 0.2890 \\
\hline
\end{tabular}




\section{Table 1B}

Summary statistics of variables for the unisegment firm and diversified firm subsamples (1998-2010).

This table displays descriptive statistics of the variables involved in our models disaggregated by firms' diversification status: unisegment firm subsample and diversified firm subsample. Excess_value is the measure developed by Berger and Ofek (1995) to assess the value created by diversifying. Skewness (return skewness), residualGO (halo-removed proxy for growth opportunities based on the residuals of the regression of $M B A R$ on Excess_value) and MBAR (the market to book assets ratio) are the three different proxies for growth opportunities relevance (GOR). numsegments (number of business segments at the 4-digit SIC code level), HERF (the Herfindahl index at the 4-digit SIC code level) and TotalEntropy (the Entropy index) are alternative measures for the level of diversification. Control variables: LTA (size), EBITsales (profitability), CAPEXsales (level of investment in current operations), DTA and LDTA (financial leverage).

\section{SUBSAMPLE A: UNISEGMENT FIRMS}

\begin{tabular}{|c|c|c|c|c|c|c|c|c|}
\hline Variable & $\mathbf{N}$ & Mean & Median & $\begin{array}{l}\text { Standard } \\
\text { deviation }\end{array}$ & Min. & Max. & $\begin{array}{c}1^{\text {st }} \\
\text { quartile }\end{array}$ & $\begin{array}{c}3^{\text {rd }} \\
\text { quartile }\end{array}$ \\
\hline ExcessValue & 1353 & 0.1393 & 0.0546 & 0.7770 & -3.2510 & 3.2245 & -0.2993 & 0.5731 \\
\hline \multicolumn{9}{|c|}{$\begin{array}{l}\text { Proxies for growth } \\
\text { opportunities }\end{array}$} \\
\hline skewness & 1093 & 0.5029 & 0.3671 & 1.9305 & -19.0788 & 17.4944 & -0.1444 & 0.9499 \\
\hline residualGO & 208 & 2.0970 & 1.2666 & 2.5483 & 0.0098 & 17.1485 & 0.6687 & 2.4015 \\
\hline MBAR & 1353 & 2.2254 & 1.5213 & 2.2931 & 0.1391 & 34.0760 & 1.0539 & 2.5254 \\
\hline \multicolumn{9}{|l|}{$\begin{array}{l}\text { Diversification } \\
\text { indexes }\end{array}$} \\
\hline numsegments & 1353 & 1 & 1 & 0 & 1 & 1 & 1 & 1 \\
\hline HERF & 1353 & 0 & 0 & 0 & 0 & 0 & 0 & 0 \\
\hline TotalEntropy & 1353 & 0 & 0 & 0 & 0 & 0 & 0 & 0 \\
\hline \multicolumn{9}{|l|}{ Control variables } \\
\hline LTA & 1353 & 6.8830 & 6.5885 & 2.2150 & 2.1436 & 12.3338 & 5.1757 & 8.8116 \\
\hline EBIT/sales & 1353 & 0.0626 & 0.0812 & 0.2364 & -3.0539 & 0.7455 & 0.0253 & 0.1598 \\
\hline CAPEX/sales & 1353 & 0.0920 & 0.0413 & 0.2292 & 0.0001 & 4.0955 & 0.0202 & 0.0913 \\
\hline DTA & 1353 & 0.2389 & 0.2351 & 0.1818 & 0 & 0.8394 & 0.0759 & 0.3585 \\
\hline LDTA & 1353 & 0.1936 & 0.1759 & 0.1688 & 0 & 0.7885 & 0.0333 & 0.2975 \\
\hline
\end{tabular}

SUBSAMPLE B: DIVERSIFIED FIRMS

\begin{tabular}{|c|c|c|c|c|c|c|c|c|}
\hline Variable & $\mathbf{N}$ & Mean & Median & $\begin{array}{l}\text { Standard } \\
\text { deviation }\end{array}$ & Min. & Max. & $\begin{array}{c}1^{\text {st }} \\
\text { quartile }\end{array}$ & $\begin{array}{c}3^{\text {rd }} \\
\text { quartile }\end{array}$ \\
\hline ExcessValue & 2700 & 0.0788 & 0.0746 & 0.9293 & -4.2895 & 4.9300 & -0.4928 & 0.6504 \\
\hline \multicolumn{9}{|c|}{$\begin{array}{l}\text { Proxies for growth } \\
\text { opportunities }\end{array}$} \\
\hline skewness & 2184 & 0.4700 & 0.3724 & 1.5860 & -7.3757 & 17.0449 & -0.1212 & 0.9296 \\
\hline residualGO & 668 & 1.9892 & 1.2277 & 2.5807 & 0.0018 & 22.7588 & 0.6098 & 2.3264 \\
\hline MBAR & 2700 & 2.2931 & 1.5538 & 2.3538 & 0.2463 & 28.4187 & 1.0949 & 2.4784 \\
\hline \multicolumn{9}{|l|}{$\begin{array}{l}\text { Diversification } \\
\text { indexes }\end{array}$} \\
\hline numsegments & 2700 & 2.3255 & 2 & 0.5935 & 2 & 5 & 2 & 3 \\
\hline HERF & 2700 & 0.3628 & 0.4033 & 0.1791 & 0.0003 & 0.7833 & 0.2153 & 0.4948 \\
\hline
\end{tabular}


This work is licensed under a Creative Commons Attribution-NonCommercial-NoDerivatives 4.0 International License. This is a preprint draft of a paper accepted (17 October 2016) for publication in International Review of Financial Analysis 48 (2016) 261-271. The published version is available at: http://dx.doi.org/10.1016/j.irfa.2016.10.007

\begin{tabular}{ccccccccc} 
TotalEntropy & 2700 & 0.5785 & 0.6019 & 0.2817 & 0.0012 & 1.5681 & 0.3756 & 0.6925 \\
\hline Control variables & & & & & & & & \\
\hline LTA & 2700 & 6.5648 & 6.6323 & 1.9709 & 1.7710 & 12.5268 & 4.9905 & 7.9434 \\
EBIT/sales & 2700 & 0.0602 & 0.0807 & 0.2706 & -6.6030 & .7391 & 0.0313 & 0.1390 \\
CAPEX/sales & 2700 & 0.0599 & 0.0315 & 0.1077 & 0 & 1.7974 & 0.0184 & 0.0586 \\
DTA & 2700 & 0.2274 & 0.2237 & 0.1676 & 0 & 0.8794 & 0.0856 & 0.3368 \\
LDTA & 2700 & 0.1883 & 0.1726 & 0.1577 & 0 & 0.8362 & 0.0524 & 0.2844 \\
\hline
\end{tabular}


Table 2

Diversification level and growth opportunities [path $<<\mathrm{a}>>$, eq. (1)]

This Table reports the two-step GMM system estimations of equation [1]. Different proxies for the growth options relevance (GOR) (either skewness (return skewness),

residualGO (halo-removed proxy for growth opportunities based on the residuals of the regression of MBAR on ExcessValue) or MBAR (the market to book assets ratio)) are regressed on the degree of diversification. This degree of diversification is proxied by numsegments (number of business segments at the 4-digit SIC code level), HERF (the Herfindahl index at the 4-digit SIC code level), and TotalEntropy (the Entropy index), alternatively. Firm size (LTA), financial leverage (DTA), industry effect (dumINDUSTRY),

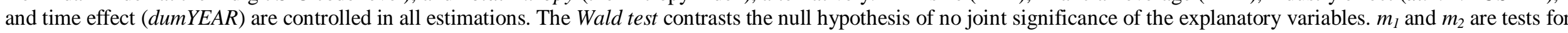
no serial correlation of first-order and second-order, respectively, in the first difference residuals. Hansen J-statistic is the test of over-identifying restrictions. The Hansen test is distributed as $\chi 2$. Standard error is shown in parentheses under coefficients. $* * * *, * *$ and $*$ denote statistical significance at the $1 \%, 5 \%$, and $10 \%$ level, respectively. Below the table, some additional tests of a U-shaped relationship between GOR and diversification are offered.

\begin{tabular}{|c|c|c|c|c|c|c|c|c|c|}
\hline \multirow[b]{2}{*}{ Constant } & \multicolumn{3}{|c|}{$\begin{array}{c}\text { Dependent variable: } \\
\text { skewness }\end{array}$} & \multicolumn{3}{|c|}{$\begin{array}{c}\text { Dependent variable: } \\
\text { residualGO }\end{array}$} & \multicolumn{3}{|c|}{$\begin{array}{l}\text { Dependent variable: } \\
\text { MBAR }\end{array}$} \\
\hline & $\begin{array}{c}2.7248^{\star * \star} \\
(0.4546)\end{array}$ & $\begin{array}{c}2.2302^{\star * \star} \\
(0.1782)\end{array}$ & $\begin{array}{c}2.2141^{\star * *} \\
(0.1698)\end{array}$ & $\begin{array}{c}3.4143^{* * *} \\
(0.3888)\end{array}$ & $\begin{array}{c}2.6126^{\star \star \star} \\
(0.3762)\end{array}$ & $\begin{array}{c}2.7507^{\star * \star} \\
(0.3688)\end{array}$ & $\begin{array}{c}3.0801^{* * *} \\
(0.1982)\end{array}$ & $\begin{array}{c}.4105^{\star \star \star} \\
(0.1899)\end{array}$ & $\begin{array}{c}3.3881^{\star \star \star} \\
(0.1874)\end{array}$ \\
\hline Diversification indexes & & & & & & & & & \\
\hline numsegments & $\begin{array}{l}-0.5403^{\star} \\
(0.2829)\end{array}$ & & & $\begin{array}{c}-0.6036^{\star * *} \\
(0.1563)\end{array}$ & & & $\begin{array}{c}-0.3177^{\star * *} \\
(0.0963)\end{array}$ & & \\
\hline numsegments2 & $\begin{array}{l}0.0970^{\star} \\
(0.0549)\end{array}$ & & & $\begin{array}{c}0.1785^{\star \star *} \\
(0.0345)\end{array}$ & & & $\begin{array}{c}0.0756^{\star \star *} \\
(0.0204)\end{array}$ & & \\
\hline HERF & & $\begin{array}{c}-1.4504^{\star * *} \\
(0.3931)\end{array}$ & & & $\begin{array}{c}-2.9561^{\star \star \star} \\
(0.5378)\end{array}$ & & & $\begin{array}{c}-2.3981^{\star \star *} \\
(0.2649)\end{array}$ & \\
\hline HERF2 & & $\begin{array}{c}2.0819^{* * *} \\
(0.6402)\end{array}$ & & & $\begin{array}{c}1.7338 \\
(1.0622)\end{array}$ & & & $\begin{array}{c}3.0609 * * * \\
(0.4347)\end{array}$ & \\
\hline TotalEntropy & & & $\begin{array}{c}-0.4504^{\star *} \\
(0.1982)\end{array}$ & & & $\begin{array}{c}-2.5934^{\star \star *} \\
(0.2452)\end{array}$ & & & $\begin{array}{c}-1.0690^{\star \star \star} \\
(0.1482)\end{array}$ \\
\hline TotalEntropy2 & & & $\begin{array}{c}0.2161 \\
(0.1677)\end{array}$ & & & $\begin{array}{c}1.7317^{\star \star *} \\
(0.2718)\end{array}$ & & & $\begin{array}{c}0.8151^{\star \star \star} \\
(0.1258)\end{array}$ \\
\hline Control variables & & & & & & & & & \\
\hline LTA & $\begin{array}{c}-0.1757^{\star \star \star} \\
(0.0376)\end{array}$ & $\begin{array}{c}-0.2053^{\star * \star} \\
(0.0198)\end{array}$ & $\begin{array}{c}-0.2040^{\star * *} \\
(.0190)\end{array}$ & $\begin{array}{c}0.1800^{* \star *} \\
(0.0232)\end{array}$ & $\begin{array}{c}0.2047^{\star \star \star} \\
(0.0278)\end{array}$ & $\begin{array}{c}0.2062^{\star \star *} \\
(0.0256)\end{array}$ & $\begin{array}{c}0.2545^{\star \star *} \\
(0.0206)\end{array}$ & $\begin{array}{c}0.1818^{\star \star \star} \\
(0.0247)\end{array}$ & $\begin{array}{c}0.1793^{\star \star \star} \\
(0.0236)\end{array}$ \\
\hline DTA & $\begin{array}{c}-0.0162 \\
(0.4098)\end{array}$ & $\begin{array}{c}0.1777 \\
(0.1615)\end{array}$ & $\begin{array}{l}0.3332^{\star *} \\
(0.1579)\end{array}$ & $\begin{array}{c}-4.0630^{\star \star * *} \\
(0.1839)\end{array}$ & $\begin{array}{c}-2.9892^{\star \star \star} \\
(0.2008)\end{array}$ & $\begin{array}{c}-3.0293^{\star \star *} \\
(0.2783)\end{array}$ & $\begin{array}{c}-5.6875^{\star \star * *} \\
(0.1532)\end{array}$ & $\begin{array}{c}-5.8660^{\star \star \star \star} \\
(0.1442)\end{array}$ & $\begin{array}{c}-5.8352^{\star \star \star x} \\
(0.1378)\end{array}$ \\
\hline
\end{tabular}

\begin{tabular}{|c|c|c|c|c|c|c|c|c|c|}
\hline Industry dummies & Yes & Yes & Yes & Yes & Yes & Yes & Yes & Yes & Yes \\
\hline Year dummies & Yes & Yes & Yes & Yes & Yes & Yes & Yes & Yes & Yes \\
\hline No. of obs. & 3277 & 3277 & 3277 & 876 & 876 & 876 & 4053 & 4053 & 4053 \\
\hline Wald test & $132.22^{\star \star \star}$ & $669.00^{\star \star \star}$ & $774.46^{\star \star \star}$ & $171733.83^{\star \star \star}$ & $2558.26^{\star \star \star}$ & $901.08^{\star \star \star}$ & $5938.95^{\star \star \star}$ & $5329.57^{* \star \star}$ & $6037.98^{\star \star \star}$ \\
\hline$m_{1}$ & $-6.05^{\star \star \star}$ & $-6.06^{\star \star \star}$ & $-6.06^{\star \star \star}$ & $-2.33^{* *}$ & $-2.22^{\star \star}$ & $-2.24^{\star \star}$ & $-2.96^{\star \star \star}$ & $-2.97^{\star \star \star}$ & $-2.97^{\star \star \star}$ \\
\hline$m_{2}$ & 0.27 & 0.28 & 0.27 & 0.75 & 0.71 & 0.75 & -0.38 & -0.40 & -0.40 \\
\hline $\mathrm{p}$-value $m_{2}$ test & 0.785 & 0.780 & 0.784 & 0.451 & 0.478 & 0.453 & 0.704 & 0.687 & 0.691 \\
\hline Hansen test & 145.07 & 230.38 & 239.17 & 118.74 & 89.25 & 97.10 & 356.45 & 359.25 & 348.57 \\
\hline p-value Hansen test & 0.106 & 0.609 & 0.448 & 0.903 & 0.532 & 0.311 & 0.143 & 0.121 & 0.219 \\
\hline Sasabuchi-test of U- & $1.54^{*}$ & $2.86^{\star \star \star}$ & 0.66 & $2.69^{\star \star \star}$ & - & $3.94^{\star \star \star}$ & $2.89^{\star \star \star}$ & $5.23^{\star \star \star}$ & $5.43^{\star \star \star}$ \\
\hline
\end{tabular}
diversification 
This work is licensed under a Creative Commons Attribution-NonCommercial-NoDerivatives 4.0 International License. This is a preprint draft of a paper accepted (17 October 2016) for publication in International Review of Financial Analysis 48 (2016) 261-271. The published version is available at: http://dx.doi.org/10.1016/j.irfa.2016.10.007

\begin{tabular}{ccccccccc}
\hline $\begin{array}{c}\text { Estimated extreme } \\
\text { point }\end{array}$ & 2.7834 & 0.3483 & 1.0422 & 1.6905 & - & 0.7488 & 0.3917 & 0.6558 \\
\hline
\end{tabular}


Table 3

Diversification, growth opportunities and excess value [paths $\langle<\mathrm{c}>>,<<\mathrm{b}>>$ and $<<\mathrm{c}$ '>>, eq. (4) and (5)]

This Table reports the two-step GMM system estimations of the analysis of the mediating role of GOR in the diversification-value relationship by applying the Baron and Kenny (1986) criteria to establish mediation (equations (4) and (5)). Columns (1) to (3) contain the two-step GMM system estimations of the direct effect of diversification on ExcessValue (equation (4)). The ExcessValue is regressed on the level of diversification. This degree of diversification is proxied by numsegments (number of business segments at the 4-digit SIC code level), HERF (the Herfindahl index at the 4-digit SIC code level), and TotalEntropy (the Entropy index), alternatively. Columns (4) to (12) contain the estimation results of the regression of ExcessValue on GOR and the degree of diversification (equation (5)) to test the mediating role of GOR. Different proxies for GOR (either skewness (return skewness), residualGO (halo-removed proxy for growth opportunities based on the residuals of the regression of MBAR on ExcessValue) or $M B A R$ (the market to book assets ratio)) are used. Profitability (EBITsales), level of investment in current operations (CAPEXsales), financial leverage (LDTA), firm size (LTA) and its square (LTA2), industry effect (dumINDUSTRY), and time effect (dumYEAR) are controlled in all estimations.The Wald test contrasts the null hypothesis of no joint significance of the explanatory variables. $m_{1}$ and $m_{2}$ are tests for no serial correlation of first-order and second-order, respectively, in the first difference residuals. The Hansen $J$-statistic is the test of overidentifying restrictions. The Hansen test is distributed as $\chi 2$. Standard error is shown in parentheses under coefficients. ****, ** and * denote statistical significance at the $1 \%, 5 \%$ and $10 \%$ level, respectively.

\begin{tabular}{|c|c|c|c|c|c|c|c|c|c|c|c|c|}
\hline & \multicolumn{3}{|c|}{$\begin{array}{l}\text { Dependent variable: EXCESS VALUE } \\
{[\text { Path }\langle<c>>\text { (without mediators)] }}\end{array}$} & \multicolumn{9}{|c|}{$\begin{array}{c}\text { Dependent variable: EXCESS VALUE } \\
{\left[\text { Path }\left\langle<c^{\prime}\right\rangle>\text { (with mediators)] }\right.}\end{array}$} \\
\hline & $(1)$ & (2) & (3) & (4) & (5) & (6) & (7) & (8) & (9) & (10) & (11) & (12) \\
\hline $\begin{array}{c}\text { Constant } \\
\text { Growth } \\
\text { opportunities } \\
\text { proxies }\end{array}$ & $\begin{array}{l}-2.8711^{\star \star \star} \\
(0.0294)\end{array}$ & $\begin{array}{l}-2.9938^{\star \star \star} \\
(0.0272)\end{array}$ & $\begin{array}{l}-2.9983^{\star \star \star} \\
(0.0245)\end{array}$ & $\begin{array}{l}-3.4505^{\star \star \star} \\
(0.8649)\end{array}$ & $\begin{array}{l}-2.9289^{\star \star \star} \\
(0.1823)\end{array}$ & $\begin{array}{l}-2.5749^{\star \star \star} \\
(0.2571)\end{array}$ & $\begin{array}{l}-3.8031^{* \star *} \\
(0.9351)\end{array}$ & $\begin{array}{l}-3.0801^{* \star \star} \\
(01454)\end{array}$ & $\begin{array}{l}-3.0242^{\star \star \star} \\
(0.3775)\end{array}$ & $\begin{array}{l}-3.8105^{\star \star \star} \\
(0.9284)\end{array}$ & $\begin{array}{l}-3.2229^{\star \star \star} \\
(0.8433)\end{array}$ & $\begin{array}{l}-3.0108^{\star \star \star} \\
(0.3786)\end{array}$ \\
\hline skewness & & & & $\begin{array}{l}0.0465^{\star} \\
(0.0276)\end{array}$ & & & $\begin{array}{c}0.0800^{* * \star} \\
(0.0293)\end{array}$ & & & $\begin{array}{c}0.0774^{\star \star *} \\
(0.0289)\end{array}$ & & \\
\hline residualGo & & & & & $\begin{array}{l}0.1719^{\star \star \star} \\
(0.0046)\end{array}$ & & & $\begin{array}{l}0.1684^{\star \star \star} \\
(0.0035)\end{array}$ & & & $\begin{array}{c}0.2044^{\star \star \star} \\
(0.0261)\end{array}$ & \\
\hline MBAR & & & & & & $\begin{array}{l}0.1713^{\star \star *} \\
(0.0085)\end{array}$ & & & $\begin{array}{l}0.1782^{\star \star \star} \\
(0.0135)\end{array}$ & & & $\begin{array}{c}0.1792^{\star \star *} \\
(0.0134)\end{array}$ \\
\hline $\begin{array}{l}\text { Diversification } \\
\text { indexes }\end{array}$ & & & & & & & & & & & & \\
\hline numsegments & $\begin{array}{c}-0.0797^{\star \star *} \\
(0.0019)\end{array}$ & & & $\begin{array}{c}-0.1275 \\
(0.1098)\end{array}$ & $\begin{array}{l}-0.0054 \\
(0.0140)\end{array}$ & $\begin{array}{c}-0.0823^{\star \star} \\
(0.0318)\end{array}$ & & & & & & \\
\hline HERF & & $\begin{array}{c}-0.3111^{\star \star *} \\
(0.0065)\end{array}$ & & & & & $\begin{array}{l}-0.7295^{\star} \\
(0.3991)\end{array}$ & $\begin{array}{c}0.0306 \\
(0.0713)\end{array}$ & $\begin{array}{l}-0.2318 \\
(0.1432)\end{array}$ & & & \\
\hline TotalEntropy & & & $\begin{array}{c}-0.2165^{\star \star \star} \\
(0.0043)\end{array}$ & & & & & & & $\begin{array}{l}-0.4389^{\star} \\
(0.2445)\end{array}$ & $\begin{array}{c}0.2237 \\
(0.2810)\end{array}$ & $\begin{array}{l}-0.1526^{*} \\
(0.0895)\end{array}$ \\
\hline $\begin{array}{c}\text { Control } \\
\text { variables }\end{array}$ & & & & & & & & & & & & \\
\hline EBITsales & $\begin{array}{c}0.1057^{\star * *} \\
(0.0018)\end{array}$ & $\begin{array}{c}0.0870^{\star \star *} \\
(0.0018)\end{array}$ & $\begin{array}{c}0.0884^{* * *} \\
(0.0018)\end{array}$ & $\begin{array}{c}0.0448 \\
(0.1840)\end{array}$ & $\begin{array}{c}1.6905^{\star \star *} \\
(0.0841)\end{array}$ & $\begin{array}{l}-0.1035^{\star \star} \\
(0.0481)\end{array}$ & $\begin{array}{l}-0.0078 \\
(0.1949)\end{array}$ & $\begin{array}{c}2.1602^{\star * \star} \\
(0.1076)\end{array}$ & $\begin{array}{l}-0.0629 \\
(0.0601)\end{array}$ & $\begin{array}{l}-0.0078 \\
(0.1924)\end{array}$ & $\begin{array}{c}2.2002^{\star \star \star} \\
(0.6130)\end{array}$ & $\begin{array}{l}-0.0690 \\
(0.0598)\end{array}$ \\
\hline CAPEXsales & $\begin{array}{r}0.8137^{\star \star \star} \\
(0.0063)\end{array}$ & $\begin{array}{c}0.7755^{\star \star *} \\
(0.0054)\end{array}$ & $\begin{array}{l}0.7817^{\star \star \star \star} \\
(0.0054)\end{array}$ & $\begin{array}{c}0.0471 \\
(0.6216)\end{array}$ & $\begin{array}{l}3.0228^{\star \star *} \\
(0.2836)\end{array}$ & $\begin{array}{l}0.6318^{* \star *} \\
(0.0764)\end{array}$ & $\begin{array}{c}0.1063 \\
(0.6050)\end{array}$ & $\begin{array}{l}3.8433^{\star \star \star} \\
(0.3010)\end{array}$ & $\begin{array}{l}0.3836^{\star} \\
(0.2320)\end{array}$ & $\begin{array}{c}0.0577 \\
(0.6073)\end{array}$ & $\begin{array}{l}1.2577 \\
(1.9551)\end{array}$ & $\begin{array}{c}0.3717 \\
(0.2317)\end{array}$ \\
\hline LDTA & $\begin{array}{c}-1.0700^{\star \star \star} \\
(0.0064)\end{array}$ & $\begin{array}{c}-1.1389 * * * \\
(0.0037)\end{array}$ & $\begin{array}{l}-1.1281^{\star \star \star} \\
(0.0045)\end{array}$ & $\begin{array}{l}-0.6711 \\
(0.4777)\end{array}$ & $\begin{array}{c}-0.4578^{\star \star \star} \\
(0.0775)\end{array}$ & $\begin{array}{l}-0.4265^{\star \star \star} \\
(0.1047)\end{array}$ & $\begin{array}{l}-0.9091^{\star} \\
(0.5034)\end{array}$ & $\begin{array}{l}-0.1316 \\
(0.1045)\end{array}$ & $\begin{array}{l}-0.3758^{\star} \\
(0.2224)\end{array}$ & $\begin{array}{l}-0.8605^{\star} \\
(0.5022)\end{array}$ & $\begin{array}{l}-0.0051 \\
(0.8213)\end{array}$ & $\begin{array}{l}-0.3833^{\star} \\
(0.2237)\end{array}$ \\
\hline LTA & $\begin{array}{l}0.9231^{\star \star \star} \\
(0.0070)\end{array}$ & $\begin{array}{c}0.9426^{\star \star *} \\
(0.0065)\end{array}$ & $\begin{array}{l}0.9431^{* \star *} \\
(0.0061)\end{array}$ & $\begin{array}{l}1.1358^{* \star *} \\
(0.2713)\end{array}$ & $\begin{array}{l}0.5438^{\star \star \star *} \\
(0.0672)\end{array}$ & $\begin{array}{l}0.6741^{* \star *} \\
(0.0810)\end{array}$ & $\begin{array}{l}1.2114^{\star * \star} \\
(0.2857)\end{array}$ & $\begin{array}{l}0.5723^{\star \star \star} \\
(0.0484)\end{array}$ & $\begin{array}{l}0.7712^{\star \star \star} \\
(0.1192)\end{array}$ & $\begin{array}{l}1.2115^{\star \star \star} \\
(0.2830)\end{array}$ & $\begin{array}{l}0.5245^{\star} \\
(0.2826)\end{array}$ & $\begin{array}{c}0.7647 * * \star \\
(0.1191)\end{array}$ \\
\hline
\end{tabular}


This work is licensed under a Creative Commons Attribution-NonCommercial-NoDerivatives 4.0 International License. This is a preprint draft of a paper accepted (17 October 2016) for publication in International Review of Financial Analysis 48 (2016) 261-271. The published version is available at: http://dx.doi.org/10.1016/j.irfa.2016.10.007

\begin{tabular}{|c|c|c|c|c|c|c|c|c|c|c|c|c|}
\hline LTA2 & $\begin{array}{c}-0.0562^{\star \star \star} \\
(0.0005)\end{array}$ & $\begin{array}{c}-0.0573^{\star \star \star} \\
(0.0004)\end{array}$ & $\begin{array}{c}-0.0573^{\star \star *} \\
(0.0004)\end{array}$ & $\begin{array}{c}-0.0729^{\star \star \star} \\
(0.0187)\end{array}$ & $\begin{array}{c}-0.0249 * \star * \\
(0.0051)\end{array}$ & $\begin{array}{c}-0.0410^{\star \star \star} \\
(0.0058)\end{array}$ & $\begin{array}{c}-0.0768^{\star \star \star *} \\
(0.0197)\end{array}$ & $\begin{array}{c}-0.0288^{\star \star \star} \\
(0.0039)\end{array}$ & $\begin{array}{c}-0.0466 * \star \star \\
(0.0083)\end{array}$ & $\begin{array}{c}-0.0768^{\star \star \star} \\
(0.0195)\end{array}$ & $\begin{array}{l}-0.0213 \\
(0.0202)\end{array}$ & $\begin{array}{c}-0.0460 \star \star \star \\
(0.0083)\end{array}$ \\
\hline \multirow{2}{*}{$\begin{array}{c}\text { Industry } \\
\text { dummies } \\
\text { Year dummies }\end{array}$} & Yes & Yes & Yes & Yes & Yes & Yes & Yes & Yes & Yes & Yes & Yes & Yes \\
\hline & Yes & Yes & Yes & Yes & Yes & Yes & Yes & Yes & Yes & Yes & Yes & Yes \\
\hline No. of obs. & 4053 & 4053 & 4053 & 3277 & 876 & 4053 & 3277 & 876 & 4053 & 3277 & 876 & 4053 \\
\hline \multirow{5}{*}{$\begin{array}{c}\text { Wald test } \\
m_{1} \\
m_{2} \\
\text { p-value } m_{2} \\
\text { test } \\
\text { Hansen test } \\
\text { p-value } \\
\text { Hansen test }\end{array}$} & $3.23 \mathrm{e}+07^{\star * *}$ & $3.15 \mathrm{e}+07^{* * *}$ & $9.01 \mathrm{e}+07^{* \star *}$ & $57.10^{\star \star \star \star}$ & $361994.51^{\star \star \star}$ & $1008.01^{\star \star \star}$ & $64.60^{\star \star \star}$ & $200982.38^{\star \star \star}$ & $557.03^{\star \star \star}$ & $64.62^{\star \star \star}$ & $633.99^{\star \star \star}$ & $562.06^{\star \star \star}$ \\
\hline & $\begin{array}{c}-9.80^{* \star *} \\
-0.87\end{array}$ & $\begin{array}{c}-9.80^{\star \star \star} \\
-0.8\end{array}$ & $\begin{array}{c}-9.79^{\star \star \star} \\
-0.88\end{array}$ & $\begin{array}{c}-8.44^{\star \star \star} \\
-1.10\end{array}$ & $\begin{array}{c}-4.12^{\star \star \star} \\
0.66\end{array}$ & $\begin{array}{c}-8.59^{\star \star \star} \\
-1.56\end{array}$ & $\begin{array}{c}-8.35^{\star \star \star} \\
-0.78\end{array}$ & $\begin{array}{c}-3.92^{* * *} \\
0.87\end{array}$ & $\begin{array}{c}-8.29^{\star \star \star} \\
-1.58\end{array}$ & $\begin{array}{c}-8.34^{\star \star *} \\
-0.83\end{array}$ & $\begin{array}{c}-3.87^{\star * *} \\
0.22\end{array}$ & $\begin{array}{c}-8.26^{\star \star \star} \\
-1.59\end{array}$ \\
\hline & 0.384 & 0.377 & 0.378 & 0.271 & 0.510 & 0.118 & 0.433 & 0.384 & 0.115 & 0.408 & 0.823 & 0.111 \\
\hline & 560.76 & 558.61 & 555.14 & 42.34 & 126.09 & 213.09 & 43.41 & 134.94 & 160.00 & 43.28 & 41.14 & 160.44 \\
\hline & 0.471 & 0.497 & 0.538 & 0.626 & 0.989 & 0.142 & 0.581 & 0.978 & 0.171 & 0.587 & 0.294 & 0.165 \\
\hline
\end{tabular}


This work is licensed under a Creative Commons Attribution-NonCommercial-NoDerivatives 4.0 International License. This is a preprint draft of a paper accepted (17 October 2016) for publication in International Review of Financial Analysis 48 (2016) 261-271. The published version is available at: http://dx.doi.org/10.1016/j.irfa.2016.10.007

\section{Table 4}

Sobel test results of mediation

This table shows the results of the Sobel test for the statistical significance of the indirect effect of the level of diversification on ExcessValue through the mediator GOR (path $\left\langle<\mathrm{c}^{\prime}>>\right.$ in Figure 1). The independent variable (IV) is the level of diversification proxied by either numsegments (number of business segments at the 4-digit SIC code level), HERF (the Herfindahl index at the 4-digit SIC code level), or TotalEntropy (the Entropy index). The mediator is GOR proxied by either skewness (return skewness), residualGO (halo-removed proxy for growth opportunities based on the residuals of the regression of MBAR on ExcessValue), or MBAR (the market to book assets ratio). The dependent variable (DV) is the ExcessValue measure developed by Berger and Ofek (1995). The square term of diversification is introduced as a covariate variable in all regressions. ***, **, and * denote statistical significance at the $1 \%, 5 \%$, and $10 \%$ level, respectively.

\begin{tabular}{|c|c|c|c|c|c|}
\hline IV & Mediator & DV & Covariate variables & Sobel test (z) & $\begin{array}{c}\text { Proportion of } \\
\text { total effect } \\
\text { mediated }\end{array}$ \\
\hline numsegments & skewness & ExcessValue & numsegments2 & -0.0027 & 0.0186 \\
\hline HERF & skewness & ExcessValue & HERF2 & -0.0070 & 0.0205 \\
\hline TotalEntropy & skewness & ExcessValue & TotalEntropy2 & -0.0036 & 0.0193 \\
\hline numsegments & residualGO & ExcessValue & numsegments2 & -0.0958 & 0.1192 \\
\hline HERF & residualGO & ExcessValue & HERF2 & $-0.5462^{\star}$ & 0.3194 \\
\hline TotalEntropy & residualGO & ExcessValue & TotalEntropy2 & $-0.3746^{\star \star}$ & 0.3327 \\
\hline numsegments & MBAR & ExcessValue & numsegments2 & $-0.0537^{\star \star \star}$ & 0.3139 \\
\hline HERF & MBAR & ExcessValue & HERF2 & $-0.1615^{\star \star \star}$ & 0.3569 \\
\hline TotalEntropy & MBAR & ExcessValue & TotalEntropy2 & $-0.1094^{\star \star \star}$ & 0.3540 \\
\hline
\end{tabular}

